\title{
PENDEKATAN KOMPARATIF DALAM ANTROPOLOGI HUKUM
}

\author{
NAMA:ILHAM PRATAMA \\ NO BP:2010003600118 \\ EMAIL:pratamailham0810@gmail.com \\ UNIVERSITAS EKASAKTI
}

\section{A. PENDAHULUAN}

1. Latar Belakang

Secara faktual, masalah-masalah yang dirumuskan ke dalam dua point utama itu sudah terjadi, baik berkenaan dengan munculnya konflik horisontal di pelbagai wilayah, pertikaian antara state (maupun pemda) dengan masyarakat, maupun antar kelompok masyarakat sendiri. Hukum, menurut Benda-Beckmann (1979; 113-114) adalah suatu cara khusus untuk membatasi otonomi anggota-anggota masyarakat. Kebanyakan penulis menyetujui bahwa hukum adalah suatu bentuk pengawasan sosial, itulah mengapa secara esensial sifatnya normatif, dan hal itu merujuk pada apa yang disebut (sebagai) konsepsi-konsepsi yang obyektif.

Implikasi pendekatan semacam ini adalah: bahwa hukum memberi inputkepada pranata pengendalian sosial (apapun variant-nya) dan kemudian kepada rujukan berpikir masyarakat, dan sebaliknya. Hukum, di sisi lain, dapat pula menyebabkan perubahan perangkat berpikir, dan rujukan kemasyarakatan lainnya atau dikenal dalam sosiologi hukum sebagai "law as tool of social engineering”. Namun, bila kesemua hal itu berubah (dan pada kenyataannya memang selalu demikian), maka hukum pun berubah mengikuti perubahan masyarakat dan lingkungannya.

Pendekatan antropologi (hukum) sengaja menggeser pusat perhatian dari aturan-aturan kepada individu atau manusia sebagai aktor yang dalam mengambil keputusan mengenai perilakunya dihadapkan kepada tuntutan-tuntutan dari tatanan hukum yang dihadapinya (Ihromi, 
2000: 3). Sejalan dengan itu, Spiertz dan Wiber (1979: 3) menegaskan, bahwa: "But to study the real position of people in relation to law requires a different methodological approach from that used in traditional legal studies. The focus to have to swift away from law as a codified or custumary set of rules and turn instead to the individual who stands at the intersection point of many different legal domains (dikutip dari Ihromi, 2000). Kajian yang diusulkan tersebut lazimnya disebut sebagai kajian terhadap gejala hukum empiris (law in action).

Dengan demikian, hukum dalam lingkup kajian Antropologi Hukum (selanjutnya ditulis A.H.) ditanggapi sebagai gejala empirik yang terjadi dalam kehidupan masyarakat. Hukum dalam konteks ini tidak ditanggapi seperti halnya para yuris mengkaji hukum (secara dogmatik).

2. Rumusan Masalah

1. Jelaskan kajian antropologi hukum?

2. Jelaskan kondisi State Law dan Other Law di Indonesia?

\section{B. PEMBAHASAN}

\section{A. Kajian Antropologi Hukum}

Di dalam perkembangan antropologi, masalah hukum sebenarnya juga sudah pernah ditelaah, walaupun di dalam suatu kerangka kebudayaan yang serba luas. Sarjana-sarjana antropologi seperti Barton, Radcliffe-Brown, Malinowski dan lainnya, pernah memusatkan perhatian pada hukum sebagai suatu gejala sosial-budaya. Sesudah embrio dari antropologi hukum timbul, maka pandangan para sarjana seperti Schapera, Gluckman, Hoebel, Bohannan, Pospisil, Nader dan lainnya mempunyai peranan besar di dalam perkembangan A.H. (Soekanto, 1984: 159-160). 
Implikasi pendekatan semacam ini adalah: bahwa hukum memberi input kepadapranatapengendaliansosial(apapun variant-nya) dan kemudian kepada rujukan berpikir masyarakat, dan sebaliknya. Hukum, di sisi lain, dapat pula menyebabkan perubahan perangkat berpikir, dan rujukan kemasyarakatan lainnya atau dikenal dalam sosiologi hukum sebagai "law as tool of social engineering". Namun, bila kesemua hal itu berubah (dan pada kenyataannya memang selalu demikian), maka hukum pun berubah mengikuti perubahan masyarakat dan lingkungannya.

Pendekatan antropologi (hukum) sengaja menggeser pusat perhatian dari aturan-aturan kepada individu atau manusia sebagai aktor yang dalam mengambil keputusanmengenaiperilakunyadihadapkan kepada tuntutan-tuntutan dari tatanan hukum yang dihadapinya (Ihromi, 2000: 3). Sejalan dengan itu, Spiertz dan Wiber (1979: 3)

Dengan demikian, hukum dalam lingkup kajian Antropologi Hukum (selanjutnya ditulis A.H.) ditanggapi sebagai gejala empirik yang terjadi dalam kehidupan masyarakat. Hukum dalam konteks ini tidak ditanggapi seperti halnya para yuris mengkaji hukum (secara dogmatik).

Secara umum metode AH adalah sebagai berikut: (a). deskriptif - yakni pemerian gejala hukum empirik dalam masyarakat yang diteliti; (b). ideology (menelusuri aturan normatifnya); (c). telaah kasus (case study method), ditambah dengan metode komparasi (perbandingan). Metode yang satu ini mendorong, antara lain diberlakukannya konsepsi cultural relativism (relativisme budaya).

Pendekatan berikutnya yang kemudian populer, dan beberapa bagiannya hingga kini masih diterapkan oleh banyak pengkaji antropologi hukum adalah: pendekatan terhadap penyelesaian sengketa (trouble cases). Pendekatan itu, umumnya, menelusuri sebab-sebab sengketa, pihak-pihak yang terlibat dan bagaimana penyelesainnya (termasuk siapa yang 
menyelesaikan, dan bagaimana sanksi yang diterapkannya). Sengketa itu hal yang melekat pada hubungan sosial, sehingga: a) bila hubungannya erat, maka penyelesaiannya cenderung damai ("win-win solution"); b) bila hubungannya renggang, maka penyelesaiannya cenderung adjudication (semacam win - loose solution). Dalam konteks ini, juga ditelaah mengenai lembaga hukum yakni: lembaga yang digunakan oleh warga untuk menyelesaikan sengketa yang timbul di antara para warga dan merupakan alat untuk tindakan balasan (counteract) setiap penyalahgunaan yang menyolok dan berat dari aturan yang ada pada lembaga lain dalam masyarakat. Tujuan menelusuri proses sengketa adalah untuk menemukan "intisari" hukum. Berbagai kajian penyelesaian sengketa dari pelbagai masyarakat dan kebudayaan kemudian diungkapkan dan ditelusuri. Karena penggunaan metode komparasi untuk berbagai penyelesaian sengketa semakin sering dan mendalam, akibatnya unsur- unsur kemajemukan pun semakin terpupuk (Dahrendorf, 1959: 209).

Varian dari pendekatan proses penyelesaian sengketa antara lain adalah pendekatan yang disebut oleh van Velsen (1967) sebagai “situational analysis" atau yang terlebih dulu diperkenalkan oleh Max Gluckman (1961) sebagai extended- case method (studi kasus yang diperluas). Tujuan pendekatan ini, menurut van Velsen adalah: untuk memberi ilustrasi mengenai keteraturan tertentu dalam proses sosial, dan bukan untuk menyoroti sifat-sifat khusus perorangan. Kajian Situational analysis adalah mengenai: catatan-catatan tentang situasi- situasi yang aktual dan perilaku tertentu. Analisis situasional ini, menurut penulisnya, bertekanan pada proses, studinya mengarah pada masyarakat yang tidak stabil dan tidak homogen. Asumsi pentingnya: bahwa norma-norma dari masyarakat tidaklah merupakan totalitas yang konsisten dan koheren. Sebaliknya, norma-norma tersebut sering terumus secara kabur dan saling tidak 
sesuai. Maka, kajian mengenai norma-norma yang saling berbeda dikaitkan dengan konflik menjadi sorotan utamanya. Kembali lagi terlihat bahwa benih-benih dan pandangan tentang kemajemukan semakin menegas di sini.

\section{B. Kondisi State Law and Other Law di Indonesia}

Pada mulanya (terutama pada awal Orde Baru hingga tahun 1980an), posisi state law memang terlihat dan terkesan lebih kuat (karena ditegakkan dengan pengaruh kekuasaan dan pengaruh politik), namun mulai tahun $90^{\prime}$ an dan seterusnya posisi the other laws, setidaknya untuk bidang-bidang tertentu, semakin menguat dan menggejala (Keesing, 1992: 294).

Mengapahal tersebut terjadi?Alasannya: (a). Karena adanya tekanan pihak luar (WB, $\mathrm{ADB}, \mathrm{UN}$, dan IMF, misalnya), secara langsung maupun tidak, agar pembangunan Indonesia lebih mengedepankan upaya pemberdayaan masyarakat dan meningkatkan partisipasi mereka (padahal, upaya penegakan hukum - negara - melalui prinsip rule of law memang belum juga membaik); (b). Karena "titik sabar" masyarakat-masyarakat di pelbagai tempat sudah mencapai kulminasinya, itu karena keberadaan mereka - terutama melalui keberadaan sistem hukum dan sistem budayanya - terancam akan terus terkikis atau malah punah (Bahtiar, 2001; 10); (c). Sementara, dari sisi pemerintah, kekuasaan mereka (alias dukungan dari pelbagai pihak) mulai menyusut. Pelbagai lapisan sosio-politik semakin rasional dalam memandang perilaku dan sikap pemerintah (state). Gerak "reformasi" pun memberi dukungan terhadap perubahan tersebut; (d). Mulanya lebih sebagai "lips service" saja, yakni mencatumkan model pembangunan yang bottom up (lihat misalnya GBHN 1993 dan 1998), namun lama-kelamaan tuntutan berbagai pihak termasuk dari sebagian komponen dalam institusi state sendiri (lebih karena ketidak-berdayaan aparat) - untuk merealisasikannya menjadi semakin kuat; (e). Karena komunikasi \& kinerja 
jaringan- jaringan kerja lembaga kemasyarakatan di "akar rumput" (grass root) (oleh LSM atau Ornop) semakin menguat, dan tugas utama mereka adalah untuk memberdayakan masyarakat dan meningkatkan partisipasi serta posisi tawarnya terhadap state dan pelaku ekonomi-politik yang kuat; (f). Sejalan dengan itu, informasi dan pelbagai data kini lebih cepat diterima dan diserap oleh berbagailapisan masyarakat. Hal semacam ini, antara lain, berdampak pada terjadinya percepatan peningkatan kesadaran masyarakat akan keberadaan diri dan aturan yang melandasi atau menekannya.

Pertama, State law disusun secara terintegrasi dan hubungan antar produk hukumnya teratur, sehingga mudah diterapkan. Namun pada kenyataannya: dari segi peraturan perundangan, state law seringkali inkonsisten, terkadang saling bertentangan, cakupannya tidak begitu jelas, dan fokusnya terkadang samar serta wewenangnya saling tumpang-tindih. Bahkan, menurut penulis, juga di era reformasi sekarang ini belum ada suatu Rencana Pembangunan Hukum yang komprehensif dan terinci.

Kedua, law enforcementnya State law tidak pandang bulu. Namun kenyataannya bisa sebaliknya. Hukum sering bisa ditegakkan,terutama,bilatidakbertentangan dengan keinginan tertentu. Hukum sulit ditegakkan bila yang terlibat pelanggaran di dalamnya adalah pihak-pihak pemilik power dan pemodal kuat. Di tingkat masyarakat pun law enfocement pelbagai produk hukum tersebut dipertanyakan. Sementara, kekuatan penegakannya kalaupun cukup kuat, sesungguhnya amat tergantung pada situasi dan kondisi saat-saat tertentu; dan tergantung pula, terutama pada struktur sosio-politik yang lebih makro.

Ketiga, State law menghadirkan keadilan. Padahal, pada kenyataannya tidak selalu demikian. Bahkan, oleh sebagian masyarakat dianggap semakin memunculkan ketidakadilan. Kasus yang ramai dibicarakan yakni seorang saksi dari kejahatan para penegak hukum yang 
disuap justru diajukan sebagai tertuduh adalah salah satu indikasinya. Beberapa pihak berpendapat, bahwa walaupun negara kita adalah "negara hukum" (rechtsstaats), namun de facto-nya bisa tidak demikian. Aparatur pelaksana maupun sistem hukum negara tentunya bisa bersikap tidak adil, soalnya kedudukan dan peran mereka memang bisa menjadi tidak netral. Kekuatan sosio-politik dan agama seringkali juga mewarnai "tarik-menarik" tersebut.

Keempat, State law lebih bisa mengikuti perkembangan waktu (up to date). Namun, kenyataannya malah sebaliknya, banyak perdebatan muncul berkaitan dengan produk-produk hukum yang dianggap cepat menjadi out of date. Sekedar contoh adalah: penggantian UU No. 22/99 yang baru Januari 2001 lalu diterapkan. Contoh lainnya adalah proses pergantian UU No. 18/97 dengan UU No. 34/2000. Bahkan contoh mengenai perubahan SK Menteri Tenaga Kerja (dan Transmigrasi) di alinea berikut yang begitu cepat adalah contoh cepatnya out of date suatu peraturan penting. Belum lagi bila kita membicarakan peraturan perundangan di bidang perbankan dan perekonomian, misalnya mengenai money laundering. Di sisi lain, landasan untuk menentukan "kuno" tidaknya sebuah peraturan perundangan itu kadangkala juga kurang jelas.

Kelima, State law dianggap berperan netral dan tidak memihak. Namun kenyataannya, tidak selalu demikian. Contoh pergantian SK Menteri Tenaga Kerja No. 150/2000 yang dianggap pengusaha terlalu "memberi angin" pada buruh dengan Kepmenakertrans No. 78 Tahun 2001, (dan karena mendapat tekanan buruh) lalu diganti lagidenganKepmenakertransNo.111tahun 2001 (dan kemudian dibekukan karena menimbulkan protes yang berkembang dari kalangan pengusaha) adalah contoh kasusnya. Ketidak konsistenan peraturan maupun penegakannya malah terlihat kembali, yakni dengan diberlakukannya kembali SK Menteri Tenaga Kerja No. 150/2000 karena tekanan buruh yang menguat. Bila yang diatur dari kelompok yang benar-benar 
lemah, maka hasilnya akan semakin mengikis keberadaan mereka. Beberapa contoh lain tentunya dapat diwacanakan pada kesempatan lain.

Keenam, keputusan state law dapat dieksekusi sesuai dengan apa yang diaturnya. Kenyataannya, pada berbagai keputusan tidaklah demikian. Pada beberapa kasus, pelaksanaan keputusan pengadilan justru menimbulkan permasalahan. Contoh yang cukup dikenal di kalangan pengamat kajian hukum adat adalah kasus: harta "Juma Pasar" di Karo (Keputusan MA tahun 1961 tentang pembagian warisan tanah adat) yang hingga kini tidak dapat dieksekusi. Keputusan hukum, selain dilandasi oleh aturan-aturan formal, yang lebih penting lagi haruslah melahirkan rasa keadilan, kontekstual dengan ruang dan waktu dimana keputusan itu ditetapkan. Hal-hal di atas, justru lebih sering tercecer sehingga keputusan hukum (negara) sulit diterapkan untuk menyelesaikan permasalahan masyarakat di berbagai daerah. Terkadang eksekusi state law justru menimbulkan protes yang berkepanjangan di masyarakat. Mereka menganggap isi keputusannya tidak adil dan merugikannya.

Ketujuh, State law lebih berpower dibanding the other laws, pada kenyataannya tidaklah selalu demikian. Power itu, di masa yang baru lalu, diperoleh melalui berbagai kebijakan terpusat dan bertumpu pada kekuatan eksekutif yang didukung oleh lembaga yang relatif solid koordinasi dan instruksinya. Ketika dukungan power itu melemah, terutama empat tahun belakangan, maka kekuatan state law pun melemah. Power, terutama di masa yang baru lalu, lebih digunakan untuk melakukan penyeragaman, sehingga harus begitu kuat ditegakkan. Ketika itupun power yang ada sebenarnya relatif rapuh. Rapuh karena dilakukan secara terpusat, bersifat memobilisasi, dan mempertahankan pola kerja patron-client relationship. Rapuh karena dipertahankan secara represif dan (biayanya) menjadi mahal, dan dukungan masyarakatnya terus menyusut. Deretan panjang mitos pun masih dapat diwacanakan, namun yang penting adalah: 
bahwa cara pandang terhadap state law yang menghegemoni the other laws sepatutnya kini dikritisi. Alasannya, karena pada kenyataannya sisi rapuh state law pun banyak (Simbolon, 1995: 47).

\section{PENUTUP}

\section{A.Kesimpulan}

Pengkajian Antropologi Hukum telah memberikan telaah akan hasil kreasi, distribusi dan transmisi hukum yang ada. Kajian mengenai bagaimana kekuasaan hukum berproses dan memberi dampak dalam masing-masing masyarakat. Selanjutnya akan menampilkan bagaimana feed back dan pengaruh masyarakat-masyarakat terhadap kekuasaan hukum tersebut. Kemajemukan hukum yang ada di Indonesia dewasa ini merupakan soal tersendiri mengingat otetisitas Antropologi Hukum yang sejak lama menempatkan dan menghargai the other laws secara proporsional dan kontekstual. Dengan demikian para pengkaji antropologi hukum ditantang untuk memberikan kontribusi bagi perkembangan hukum di Indonesia, khususnya terkait dengan korelasi positif the other laws dengan state laws.

\section{DAFTAR PUSTAKA}

Gokma Toni Parlindungan S, Asas Nebis In Idem Dalam Putusan Hakim Dalam Perkara Poligami Di Pengadilan Negeri Pasaman Sebagai Ceriminan Ius Constitutum, Volume 2, Nomor 1, 2020.

Gokma Toni Parlindungan S, Pengisian Jabatan Perangkat Nagari Pemekaran Di Pasaman Barat Dalam Rangka Pelaksanaan Otonomi Daerah, Ensiklopedia Of Journal, Vol 1 No 2 Edisi 2 Januari 2019,

Harniwati, Peralihan Hak Ulayat Menurut Undang-Undang Nomor 18 Tahun 2004, Volume 1, Nomor 3, 2019. 
Jasmir, Pengembalian Status Hukum Tanah Ulayat Atas Hak Guna Usaha, Soumatera Law Review, Volume 1, Nomor 1, 2018.

Jumrawarsi Jumrawarsi, Neviyarni Suhaili, Peran Seorang Guru Dalam Menciptakan Lingkungan Belajar Yang Kondusif, Ensikopedia Education Review, Vol 2, No 3 (2020): Volume 2 No.3 Desember 2020

Mia Siratni, Proses Perkawinan Menurut Hukum Adatdi Kepulauan Mentawai Di Sebelum Dan Sesudah Berlakunya Undang-Undang Nomor 1 Tahun 1974 Tentang Perkawinan, Ensiklopedia Of Journal, Vol 1 No 2 Edisi 2 Januari 2019,

Remincel, Dimensi Hukum Pelanggaran Kecelakaan Lalu Dan Angkutan Jalan Lintas Di Indonesia, Ensiklopedia Social Review, Volume 1, Nomor 2, 2019.

R Amin, B Nurdin, Konflik Perwakafan Tanah Muhammadiyah di Nagari Singkarak Kabupaten Solok Indonesia 2015-2019, Soumatera Law Review, Volume 3, Nomor 1, 2020. 